\title{
Source and flux of POC in a karstic area in the Changjiang River watershed: impacts of reservoirs and extreme drought
}

\author{
Hongbing $\mathrm{Ji}^{1,2}$, Cai $\mathbf{L i}^{1}$, Huaijian Ding ${ }^{1}$, and Yang Gao ${ }^{1}$ \\ ${ }^{1}$ School of Civil \& Environmental Engineering, University of Science and Technology Beijing, 100083 Beijing, China \\ ${ }^{2}$ State Key Laboratory of Environmental Geochemistry, Institute of Geochemistry, Chinese Academy of Sciences, \\ Guiyang 550002, China
}

Correspondence to: H. Ji (hongbing_ji@163.com)

Received: 12 January 2016 - Published in Biogeosciences Discuss.: 16 March 2016

Revised: 1 June 2016 - Accepted: 3 June 2016 - Published: 23 June 2016

\begin{abstract}
Isotopes of carbon (C) and nitrogen $(\mathrm{N})$ along with $\mathrm{C} / \mathrm{N}$ ratios of particulate organic carbon (POC) were used to identify source and transformation of organic carbon in the suspended and surface sediments in a typical karstic watershed (the Wujiang River, an important tributary of the Changjiang River). Isotope data for suspended sediments indicate that POC was mainly derived from phytoplankton and C3-dominated soil with an increased contribution of phytoplankton in sites directly affected by the reservoir. In contrast, the POC in surface sediments was mainly derived from C3- and C4-dominated soil with little reservoir influence. The positive correlations of carbon and nitrogen isotopes between suspended and surface sediments indicated that these two carbon pools are tightly coupled. Our conservative estimation suggests that $1.17 \times 10^{10} \mathrm{~g}$ of POC is transported to the Three Gorges Reservoir during the study period in 2013. POC yield in the Wujiang River $\left(0.13 \mathrm{t} \mathrm{km}^{-2} \mathrm{yr}^{-1}\right)$ is much lower than those of large rivers with a high abundance of carbonate minerals. Based on the distribution pattern of POC yield, it is inferred that carbonate minerals (lithology) do not contribute significantly to the riverine POC. The cascade of reservoirs and extreme drought had a significant influence on the POC flux in the Wujiang River.
\end{abstract}

\section{Introduction}

Globally, about $0.4 \mathrm{Gt}$ of riverine organic carbon is transported to the world's oceans each year, of which $0.15-0.17 \mathrm{Gt}$ is particulate organic carbon (POC) (Hedges et al., 1997; Ludwig et al., 1996; Schlesinger and Melack, 1981). Rivers are important channels for transporting organic carbon from land to ocean. The riverine POC provides integrated information both on the natural processes and human activities within the drainage basin (Meybeck and Ragu, 1996; Kendall et al., 2001). Previous studies indicate that climate and human disturbance are two important factors of POC transport. For example, POC fluxes decrease in response to dam construction and extreme drought (Bianchi et al., 2007; Yu et al., 2011; Zhang et al., 2009) and increase in response to deforestation and flood events (Kao and Liu, 1996; Sun et al., 2007).

Riverine POC ultimately originates from terrestrial and aquatic organic matter. Because different sources of POC are characterized by distinguished $\delta^{13} \mathrm{C}_{\mathrm{POC}}, \delta^{15} \mathrm{~N}_{\mathrm{TN}}$, and $\mathrm{C} / \mathrm{N}$ ratios, these indicators have been widely used to constrain sources and transformation of riverine POC. However, some physical and chemical process can alter the original composition of element and isotopes, which should be carefully considered. For example, decomposition of organic matter decreases C / N ratios (Tremblay and Benner, 2006) and abundant inorganic nitrogen also limits the usefulness of $\mathrm{C} / \mathrm{N}$ ratios as a tracer of particulate organic matter sources (Guerra et al., 2013; Hu et al., 2006). Therefore, researchers utilize different combinations of $\delta^{13} \mathrm{C}_{\mathrm{POC}}, \delta^{15} \mathrm{~N}_{\mathrm{TN}}$, and $\mathrm{C} / \mathrm{N}$ ratios to identify the sources and calculate associated contributions of these sources. For example, Kendall et al. (2001) used C / N ratios and $\delta^{15} \mathrm{~N}_{\mathrm{TN}}$ as source criteria in $54 \%$ of the samples in four large river systems across the USA, whereas Wu et al. (2007) use $\delta^{13} \mathrm{C}_{\mathrm{POC}}$ and $\delta^{15} \mathrm{~N}_{\mathrm{TN}}$ to estimate the contribution of POC sources in the Changjiang River.

The Wujiang River drains a typical karst catchment with a cascade of reservoirs along the mainstream. The damming 
of rivers and climate may exert significant influence on the source and fate of POC delivered to the oceans. Recent studies have focused on the effects of the Three Gorges Dam and extreme drought in the Changjiang River (Bao et al., 2014; Wu et al., 2007; Yu et al., 2011). POC flux has decreased from $7.4 \times 10^{12} \mathrm{t} \mathrm{yr}^{-1}$ during 1984-1998 to $1.52 \times 10^{12} \mathrm{tyr}^{-1}$ after the impoundment of the Three Gorges Dam (Wu et al., 2007; Wang et al., 2012). However, little attention is paid to rivers draining karstic areas, which are more subject to different geochemical processes and anthropogenic activities than non-karst rivers (Liu, 2007; Ogrinc et al., 2008; Tao et al., 2009). Eleven artificial reservoirs have been constructed along the mainstream of the Wujiang River since 1970s. The related study on POC in the Wujiang River is still limited after the construction of these reservoirs. According to the Changjiang Sediment Bulletin (2013), an extreme drought occurred in most areas of Guizhou Province. Based on the analyses of $\delta^{13} \mathrm{C}_{\mathrm{POC}}$, $\delta^{15} \mathrm{~N}_{\mathrm{TN}}$, and $\mathrm{C} / \mathrm{N}$ ratios in the suspended and surface sediments in the Wujiang River, this study identified source and flux of POC in the Wujiang River and examined the impacts of reservoirs and climate.

\section{Materials and methods}

\subsection{Study sites description}

The Wujiang River is the largest tributary of the upper Changjiang River in its south bank. It originates from the eastern Wumeng Ranges in Yunnan-Guizhou Plateau and flows through Yunnan Province, Guizhou Province, Sichuan Province, and Hubei Province. It flows into the Three Gorges Reservoir in Fuling District, Chongqing Municipality. The drainage area of Wujiang River is $87920 \mathrm{~km}^{2}$, of which $76 \%$ drains in Guizhou Province. Its average annual discharge is $534 \times 10^{8} \mathrm{~m}^{3} \mathrm{yr}^{-1}$. The watershed belongs to a warm subtropical climate. The mean annual air temperature varies from 10 to $18^{\circ} \mathrm{C}$ with mean annual precipitation from 800 to $1400 \mathrm{~mm}$. The altitudes of Wujiang River range from 500 to $2400 \mathrm{~m}$ with a decreasing trend from west to east. Plant species are diverse with the upper reach dominated by broadleaf evergreen forest and dryland crop, the middle reach dominated by evergreen broadleaf forest and deciduous broadleaf mixed forest, and the lower reach dominated by subtropical evergreen Castanopsis forest. Yellow soil and limestone soil are dominant in the watershed (Zhang et al., 1995). The land use is dominated by forest land, cultivated land, and grass land, which account for 50, 31, and $18 \%$, respectively. The soil erosion rate decreased from $2678 \mathrm{t} \mathrm{km}^{-2} \mathrm{yr}^{-1}$ in 1980 s to $2313 \mathrm{t} \mathrm{km}^{-2} \mathrm{yr}^{-1}$ in 1990s due to sustainable soil conservation measures (Wang, 2011).

The Wujiang River is a typical karst watershed. In the upper reaches, Permian and Triassic carbonate rocks and basalt are dominant with coal-bearing formations outcropping in

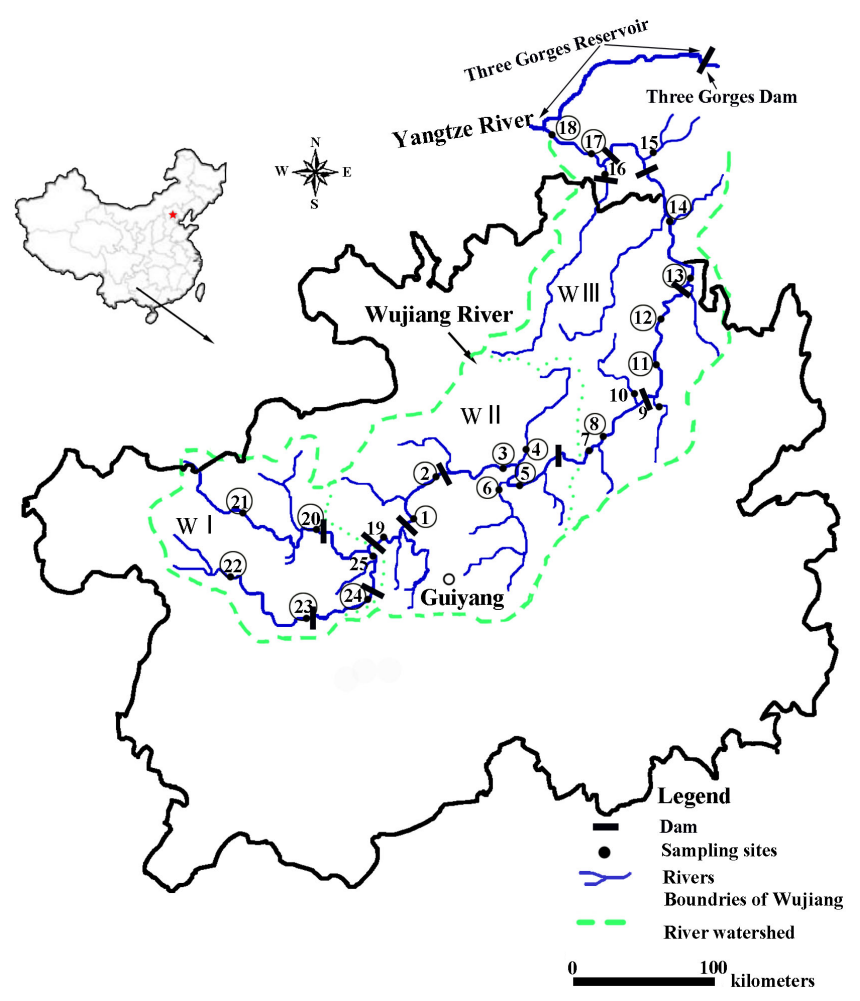

Figure 1. Location of sampling sites in the Wujiang River. Zones of W I, W II, and W III are the upper reaches, middle reaches, and lower reach, respectively. W I is dominated by Permian and Triassic carbonate rocks and basalt with coal-bearing formations outcrop in west. W II is dominated by Permian and Triassic limestones, dolomitic limestones, and dolomites. W III is distributed carbonate rocks intercalated with detrital rocks (shales, sandy shales, and siltstones).

the western area. In the midstream area, Permian and Triassic limestones, dolomitic limestones, and dolomites are dominant whereas the lower reaches are dominated by carbonate rocks intercalated with shales, sandy shales, and siltstones (Zhang et al., 1995).

\subsection{Sampling and analyses}

In all, 25 samples of suspended particulate matter (SPM) were collected from the mainstream and major tributaries of the Wujiang River (Fig. 1) in May and August 2013, respectively. In all, 18 surface sediments were sampled in August 2013. An extreme drought occurred in most Guizhou Province during June and August. Figure 2 showed the monthly water discharge and suspended sediment load in 2013 at the Wulong Hydrological Station, located at the Wujiang River mouth. The data were taken from Changjiang Sediment Bulletin (2013). As plotted in the Fig. 2, water discharge and suspended sediment load decreased abruptly from June to August due to the drought event. 
Sampling of SPM were conducted by filtration through precombusted $\left(450^{\circ}\right.$ for $\left.6 \mathrm{~h}\right)$ and preweighted $47 \mathrm{~mm}$ glass fiber filters for SPM weight concentrations and stable isotopic analyses of carbon and nitrogen. Surface sediments were collected using a $0.05 \mathrm{~m}^{2}$ Van Veen grab (Jiang and Ji, 2013). All samples were stored in a freezer $\left(\leq 20^{\circ}\right)$ prior to laboratory analyses.

The filter samples were freeze-dried before the particulate substance was scraped from the filter. The freeze-dried suspended matter and sediment were sieved to 200 mesh, treated with $1 \mathrm{M} \mathrm{HCl}$ to remove inorganic carbon, while nitrogen isotopes of particulate matter were measured on the bulk samples without acidification. Organic carbon (OC) and total nitrogen (TN) contents as well as isotopes of carbon and nitrogen were determined by using an elemental analyzer (Flash EA 1112HT, Thermo Fisher Scientific, Inc., USA) coupled with an isotope-ratio mass spectrometer (Finnigan Delta V Advantage, Thermo Fisher Scientific, Inc., USA) in the Laboratory of Stable Isotope Ratio Mass Spectrometry, Chinese Academy of Forestry (Beijing 100091, China). Stable isotope ratios are reported in $\delta$-unit notation as follows:

$\delta X(\% o)=\left(R_{\text {sample }} / R_{\text {standard }}-1\right) \times 1000$,

where $R_{\text {sample }}$ is the $\delta^{13} \mathrm{C} /{ }^{12} \mathrm{C}$ or ${ }^{15} \mathrm{~N} /{ }^{14} \mathrm{~N}$ ratios of the sample, and $R_{\text {standard }}$ is the corresponding ratios of sample standard. $\delta^{13} \mathrm{C}$ values are reported relative to Pee Dee Belemnite (PDB) and $\delta^{15} \mathrm{~N}$ values are reported relative to $\mathrm{N}_{2}$ in atmospheric air (AIR). Precision for $\delta^{13} \mathrm{C}$ is $0.2 \%$ and for $\delta^{15} \mathrm{~N}$ is $0.2 \%$.

The minerals of suspended particulate and surface sediment were analyzed in State Key Laboratory for Advanced Metals and Materials, University of Science and Technology, Beijing. To test the relationships between total suspended sediment (TSS) concentrations, elemental compositions (POC \%, TN \% and $\mathrm{C} / \mathrm{N}$ ratios), and isotopic compositions, Person's correlation coefficient (Table S2 in the Supplement) was calculated using Statistical Package for Social Science (SPSS) software (version 16.0 for Windows).

\section{Results}

\subsection{The mineral properties of suspended particulate and surface sediments}

As presented in the Fig. S1, the major minerals of SPM in the Wujiang River included detrital minerals (quartz, calcite, and dolomite), clay minerals (illite, kaolinite, and smectite), magnetite, and ilmenite. In contrast, the surface sediments contained few clay minerals, reflecting the preferential enrichment of clay minerals in SPM. The enrichment of clastic carbonate minerals in surface sediment indicated the preferential sedimentation of clastic carbonate relative to clay minerals. This was similar to the study in the Changjiang River by Ding et al. (2014). The dolomite in the SPM and sur-

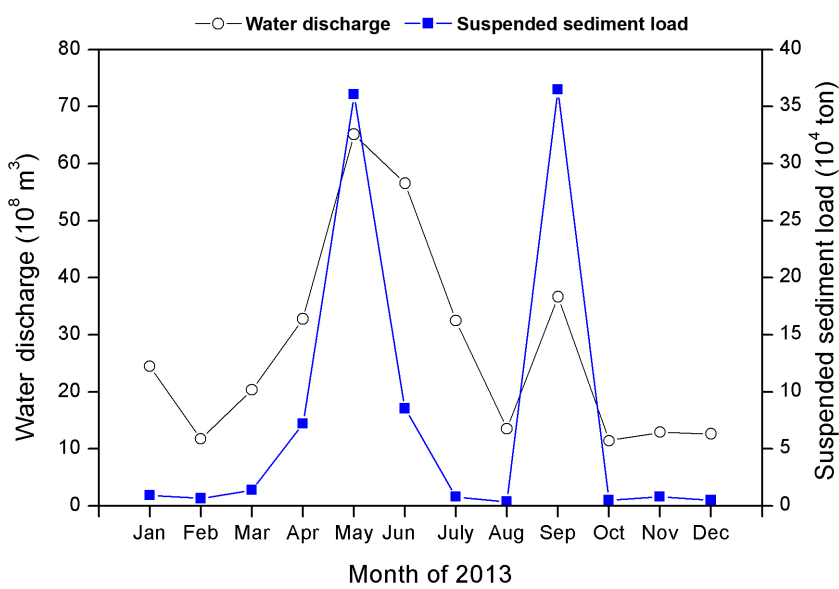

Figure 2. Monthly water discharge and suspended sediment load in 2013 at Wulong Hydrological Station. The data were taken from Changjiang Sediment Bulletin 2013 (website: www.cjw.gov.cn).

face sediment was observed in the middle and lower reaches, which was in agreement with the catchment lithology. The mineral composition of SPM and surface sediment reflected the process of physical and chemical weathering.

\subsection{Elemental and isotope composition (carbon and nitrogen) in SPM}

The ratios of carbon to nitrogen showed the wide range of 2.8-29.3, with a mean value of 13.6 in May and 8.8 in August (Table S1), indicating a source with high $\mathrm{C} / \mathrm{N}$ ratios in May and low $\mathrm{C} / \mathrm{N}$ ratios in August. Figure 3 showed the spatial and seasonal variations of $\mathrm{C} / \mathrm{N}$ ratios, $\delta^{13} \mathrm{C}_{\mathrm{POC}}$, and $\delta^{15} \mathrm{C}_{\mathrm{TN}}$ in the Wujiang River. Compared with August, more samples in May had $\mathrm{C} / \mathrm{N}$ ratios higher than 15, whereas more samples had $\mathrm{C} / \mathrm{N}$ ratios $<8$ in August, which were distributed in sites near or in reservoirs, for example sites 1, 2, and 19 (Fig. 3). Considering the cascade of reservoirs along the $\mathrm{Wu}$ jiang River, the impact of the reservoir should be examined. The sampling sites were divided into two types based on the relation with reservoirs: sites directly affected by reservoirs and less affected by reservoirs. Table 1 showed the comparison of elemental and isotopic parameters in these two types of sites. As shown in the Table $1, \mathrm{C} / \mathrm{N}$ ratios were lower in sites directly affected by reservoirs than those in sites less affected by reservoirs.

The $\delta^{13} C_{\text {POC }}$ of SPM in May ranged from -30.18 to $-21.09 \%$ and averaged $-26.30 \%$ o. Differently, $\delta^{13} \mathrm{C}_{\mathrm{POC}}$ in August displayed relatively depleted values with an average value of $-27.23 \%$ o. $\delta^{15} \mathrm{~N}_{\mathrm{TN}}$ of SPM ranged from 1.88 to $12.93 \%$ and averaged $6.82 \%$, with higher values in August $\left(7.58 \%\right.$ o) than those in May $\left(6.05 \%\right.$ o). Spatially, $\delta^{13} \mathrm{C}_{\mathrm{POC}}$ values, especially in August, were more depleted in reservoirs and sites downstream of the reservoirs $(-28.65 \pm 1.22 \%$; Table 1 and Fig. 3) than those less affected by reservoirs 

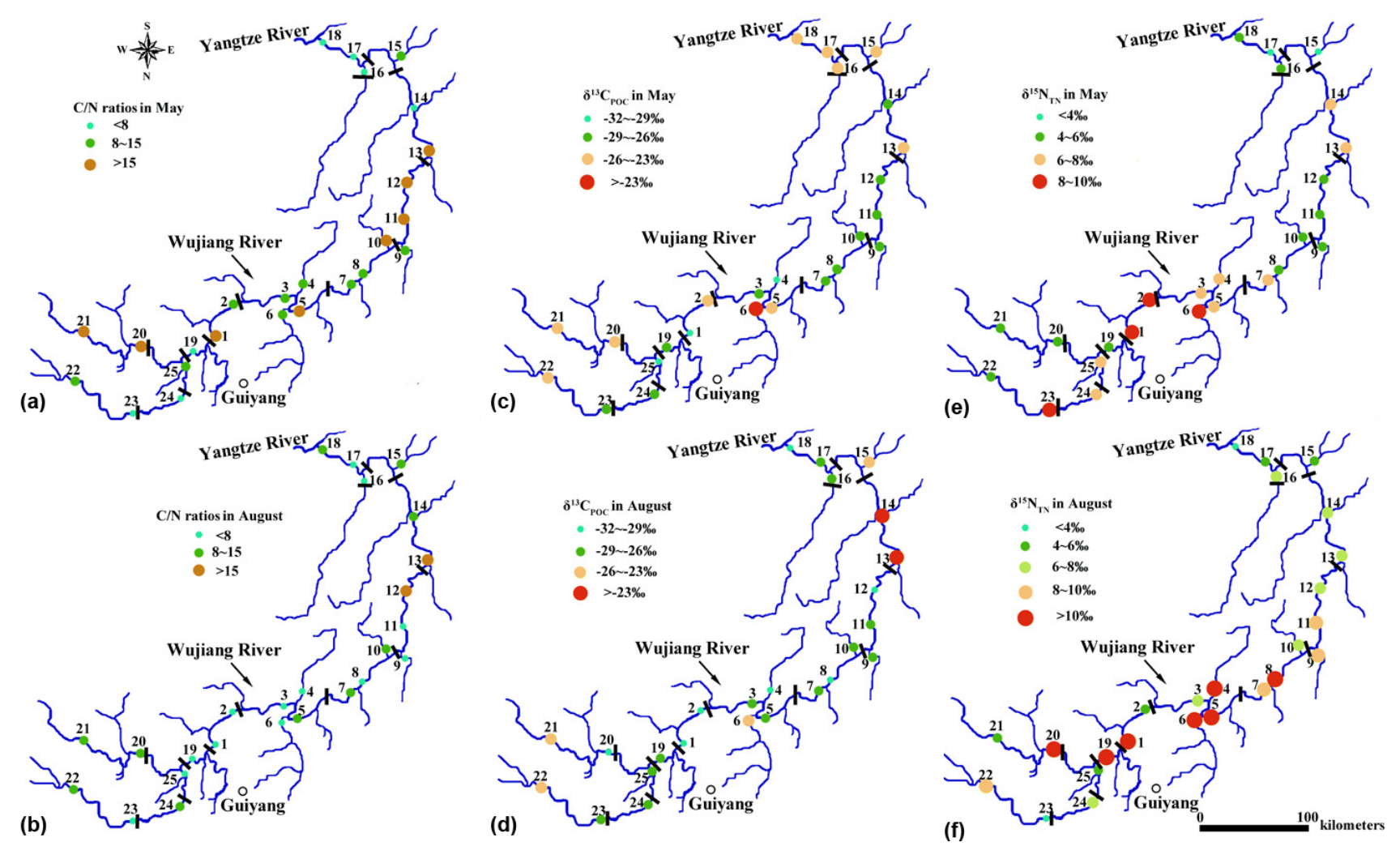

Figure 3. The spatial variations of $\mathrm{C} / \mathrm{N}$ ratios, $\delta^{13} \mathrm{C}_{\mathrm{POC}}$ and $\delta^{15} \mathrm{C}_{\mathrm{TN}}$ of suspended particulate matter in the Wujiang River.

Table 1. Comparison of TSS concentrations, $\mathrm{C} / \mathrm{N}$ ratios and isotopic values (mean \pm standard deviation) in sites affected by reservoirs with those unaffected by reservoirs in the Wujiang River.

\begin{tabular}{|c|c|c|c|c|c|c|c|c|c|c|c|c|}
\hline \multirow[t]{2}{*}{ Sites } & \multirow[t]{2}{*}{ Descriptions } & \multicolumn{2}{|c|}{ TSS $\left(\mathrm{mg} \mathrm{L}^{-1}\right)$} & \multicolumn{3}{|c|}{$\mathrm{C} / \mathrm{N}$ ratios } & \multicolumn{3}{|c|}{$\delta^{13} \mathrm{C}(\%)$} & \multicolumn{3}{|c|}{$\delta^{15} \mathrm{~N}(\% o)$} \\
\hline & & May & August & May & August & Sediment & May & August & Sediment & May & August & Sediment \\
\hline $\begin{array}{l}1,2,16 \\
19,20 \\
23,24\end{array}$ & $\begin{array}{l}\text { reservoirs and } \\
\text { downstream of } \\
\text { the reservoirs }\end{array}$ & $\begin{array}{l}5.39 \\
\pm 6.99\end{array}$ & $\begin{array}{l}3.79 \\
\pm 1.58\end{array}$ & $\begin{array}{l}13.1 \\
\pm 8.9\end{array}$ & $\begin{array}{l}5.9 \\
\pm 2.4\end{array}$ & $\begin{array}{l}18.0 \\
\pm 6.9\end{array}$ & $\begin{array}{l}-26.77 \\
\pm 1.44\end{array}$ & $\begin{array}{l}-28.65 \\
\pm 1.22\end{array}$ & $\begin{array}{l}-24.85 \\
\pm 0.91\end{array}$ & $\begin{array}{l}6.82 \\
\pm 1.97\end{array}$ & $\begin{array}{l}7.99 \\
\pm 4.12\end{array}$ & $\begin{array}{l}6.23 \\
\pm 2.22\end{array}$ \\
\hline Others & $\begin{array}{l}\text { less affected } \\
\text { by reservoirs }\end{array}$ & $\begin{array}{l}24.35 \\
\pm 33.66\end{array}$ & $\begin{array}{l}4.80 \\
\pm 3.90\end{array}$ & $\begin{array}{l}13.7 \\
\pm 7.2\end{array}$ & $\begin{array}{l}10.0 \\
\pm 3.6\end{array}$ & $\begin{array}{l}18.0 \\
\pm 10.7\end{array}$ & $\begin{array}{l}-26.11 \\
\pm 2.06\end{array}$ & $\begin{array}{l}-26.68 \\
\pm 3.23\end{array}$ & $\begin{array}{l}-24.73 \\
\pm 1.04\end{array}$ & $\begin{array}{l}5.75 \\
\pm 1.49\end{array}$ & $\begin{array}{l}7.42 \\
\pm 2.49\end{array}$ & $\begin{array}{l}5.93 \\
\pm 1.55\end{array}$ \\
\hline
\end{tabular}

$\left(-26.68 \pm 3.23 \%\right.$; Table 1 and Fig. 3). In contrast, $\delta^{15} \mathrm{~N}_{\mathrm{TN}}$ values were more enriched in sites directly affected by reservoirs than other sites. Chen and Jia (2009) obtained the similar trend of $\delta^{13} \mathrm{C}_{\mathrm{POC}}$ and $\delta^{15} \mathrm{~N}_{\mathrm{TN}}$ in a dam-controlled subtropical river. As presented by Fig. 3, the heavier $\delta^{15} \mathrm{~N}_{\mathrm{TN}}$ values (>10\%o) in August corresponded to lighter $\delta^{13} \mathrm{C}_{\mathrm{POC}}$ values and lower $\mathrm{C} / \mathrm{N}$ ratios (Fig. 3).

As shown in Table $\mathrm{S} 2, \mathrm{POC} \%$, TN \%, and $\delta^{15} \mathrm{~N}_{\mathrm{TN}}$ were significantly negatively correlated with TSS concentrations in May; i.e., POC $\%$, TN \%, and $\delta^{15} \mathrm{~N}_{\mathrm{TN}}$ decreased when TSS concentrations increased. In contrast, $\delta^{13} \mathrm{C}_{\mathrm{POC}}$ was significantly positively correlated with TSS concentrations; i.e., $\delta^{13} C_{\mathrm{POC}}$ increased when TSS concentrations increased. Similar results are obtained in the freshwater part of the Scheldt
Estuary (Hellings et al., 1999). However, the relationships between isotopic parameters and TSS concentrations in August were not significant. This might be due to the low concentrations of TSS in August, when extreme drought occurred in most Guizhou Province. No significant correlation of $\delta^{15} \mathrm{~N}_{\mathrm{TN}}$ and $\delta^{13} \mathrm{C}_{\mathrm{POC}}$ was observed, which could be related to the inorganic nitrogen in samples (Guerra et al., 2013; Hu et al., 2006).

\subsection{Compositions of element and isotopes (carbon and nitrogen) in surface sediments}

Carbon to nitrogen ratios in the surface sediments presented higher values ranging from 7.7 to 41.1 compared with those 

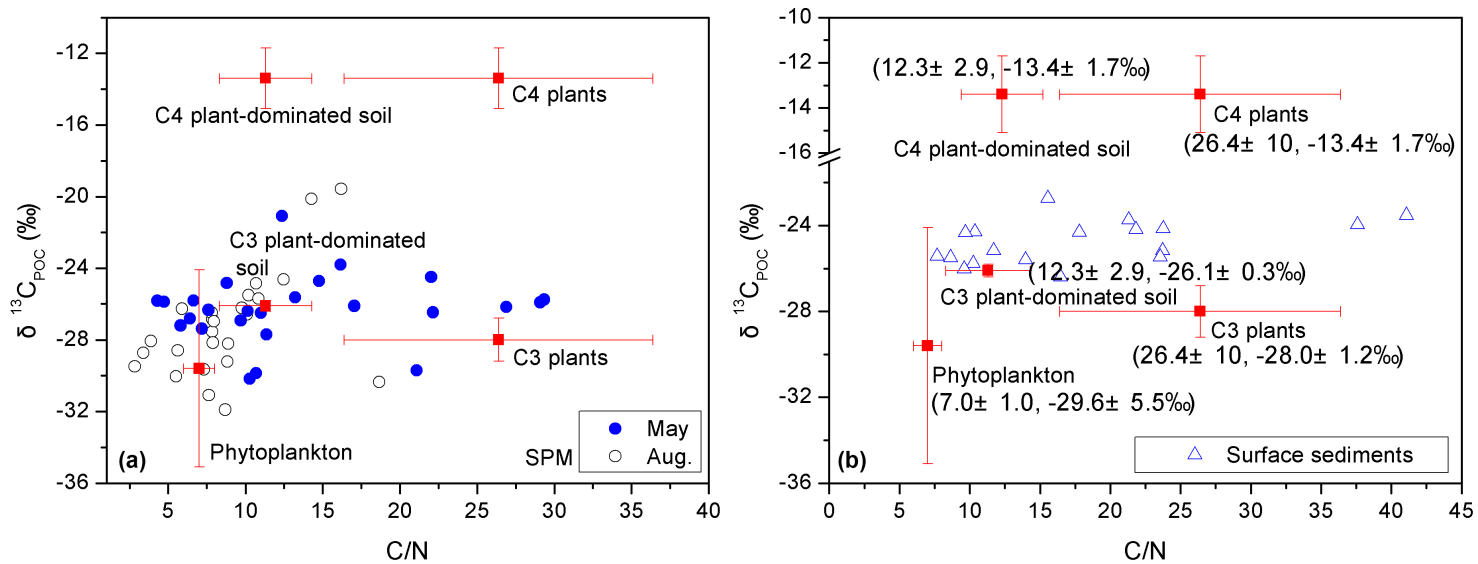

Figure 4. $\delta^{13} \mathrm{C}_{\mathrm{POC}}$ and $\mathrm{C} / \mathrm{N}$ ratios of suspended and surface sediments in the Wujiang River. The isotopic and elemental compositions of different end-members are taken from Li (2009), Wu et al. (2007), and Tao et al. (2009) and references therein.

of SPM. Like the SPM, POC \% and TN \% in surface sediments displayed a relatively significant positive correlation $(R=0.595, P<0.01)$, which indicated that some nitrogen in the sediments was inorganic nitrogen. Compared with the $\mathrm{C} / \mathrm{N}$ ratios in SPM, surface sediments had higher $\mathrm{C} / \mathrm{N}$ ratios, indicating different sources of POC in surface sediments.

$\delta^{13} \mathrm{C}_{\mathrm{POC}}$ of surface sediments showed a relatively narrow range of -26.40 to $-22.73 \%$ with an average value of $-24.76 \%$. The enriched $\delta^{13} \mathrm{C}_{\mathrm{POC}}$ of surface sediments in contrast with SPM indicated a source with elevated $\delta^{13} \mathrm{C}_{\mathrm{POC}}$ values. The variation trend of $\delta^{13} \mathrm{C}_{\mathrm{POC}}$ in surface sediments was similar to that in SPM, which indicated these two carbon pools might be coupled. $\delta^{15} \mathrm{~N}_{\mathrm{TN}}$ of surface sediments ranged from 2.88 to $9.39 \%$ with a mean value of $6.01 \%$. Spatially, the mean values of $\delta^{13} \mathrm{C}_{\mathrm{POC}}$ and $\delta^{15} \mathrm{~N}_{\mathrm{TN}}$ in sites directly affected by reservoirs and sites less affected by reservoirs were $-24.85 \pm 0.91 \%$ vs. $-24.73 \pm 1.04 \%$ and $6.23 \pm 2.22 \%$ o vs. $5.93 \pm 1.55 \%$ o (Table 1), respectively. Compared with the SPM, the difference of isotopic values were smaller in surface sediment between sites directly affected by reservoirs and sites less affected by reservoirs.

\section{Discussion}

\subsection{Sources and variations of POC in the Wujiang River}

\subsubsection{Sources of POC in SPM}

Potential sources of POC in the river contain allochthonous sources ( $\mathrm{C} 3$ and $\mathrm{C} 4$ plants, soil organic matter) and autochthonous sources (macrophytes and phytoplankton). $\mathrm{C} / \mathrm{N}$ ratios and isotopic values of $\mathrm{POC}$ are an effective method for constraining the sources of riverine POC. Generally, aquatic phytoplankton is characterized with low $\mathrm{C} / \mathrm{N}$ ratios (5-8) and terrestrial organic matter with high $\mathrm{C} / \mathrm{N}$ ratios (higher than 8, Kendall et al., 2001). Soil organic matter reflects carbon isotopic compositions of residues from the overlying vegetation with an average $\delta^{13} \mathrm{C}$ value of $-27.0 \%$ for $\mathrm{C} 3$ plants and $-14 \%$ o for C4 plants (Smith and Epstein, 1971). The typical $\delta^{15} \mathrm{~N}$ values for soil organic nitrogen are $2-5 \%$ (Kendall et al., 2001).

$\mathrm{C} / \mathrm{N}$ ratios as well as isotopic compositions of carbon are plotted in Fig. 4 together with typical values of potential endmembers of POC. As shown in the Fig. 4, C / N ratios of SPM in the Wujiang River showed temporal variations with higher C / N ratios in May (13.6 \pm 7.6$)$ than those in August $(8.8 \pm 3.7)$, which suggested the increased phytoplankton input in August. Of note, the precondition of $\mathrm{C} / \mathrm{N}$ ratios for identifying organic matter sources was that all of TN in POC exclusively reflected nitrogen bound to organic matter (Meyers, 1997). Therefore, contents of organic carbon (POC\%) and total nitrogen (TN \%) was expected to show a significant linear correlation. The linear relationship of $\mathrm{TN}$ and $\mathrm{POC}$ was relatively weak (May: $\mathrm{TN}=0.07 \times \mathrm{POC}+0.09, R^{2}=$ $0.54, \quad P<0.001$; August: $\mathrm{TN}=0.04 \times \mathrm{POC}+0.23, R^{2}=$ $0.39, P<0.001)$ compared with other studies $\left(R^{2}=0.71\right.$ in Hu et al., 2006; $R^{2}=0.9$ in Guerra et al., 2013). The intercept of the above regressions was more than zero, which suggested that a fraction of TN was inorganic nitrogen in the SPM (Guerra et al., 2013; Hu et al., 2006). Thus, the phytoplankton inputs might be overestimated based on $\mathrm{C} / \mathrm{N}$ ratios.

$\delta^{13} \mathrm{C}_{\mathrm{POC}}$ of SPM in May and August-averaged $-26.30 \%$ and $-27.23 \%$, respectively. The depleted $\delta^{13} \mathrm{C}_{\mathrm{POC}}$ in $\mathrm{Au}-$ gust indicated decreased terrestrial contribution and increased phytoplankton contribution. This was in accordance with the conclusion deduced from the $\mathrm{C} / \mathrm{N}$ ratios. The $\mathrm{Wu}-$ jiang River had high flow rates and rocky river beds and banks, which limited the macrophytes growth. Thus, phytoplankton was the main aquatic plants in the catchment (Tao et 

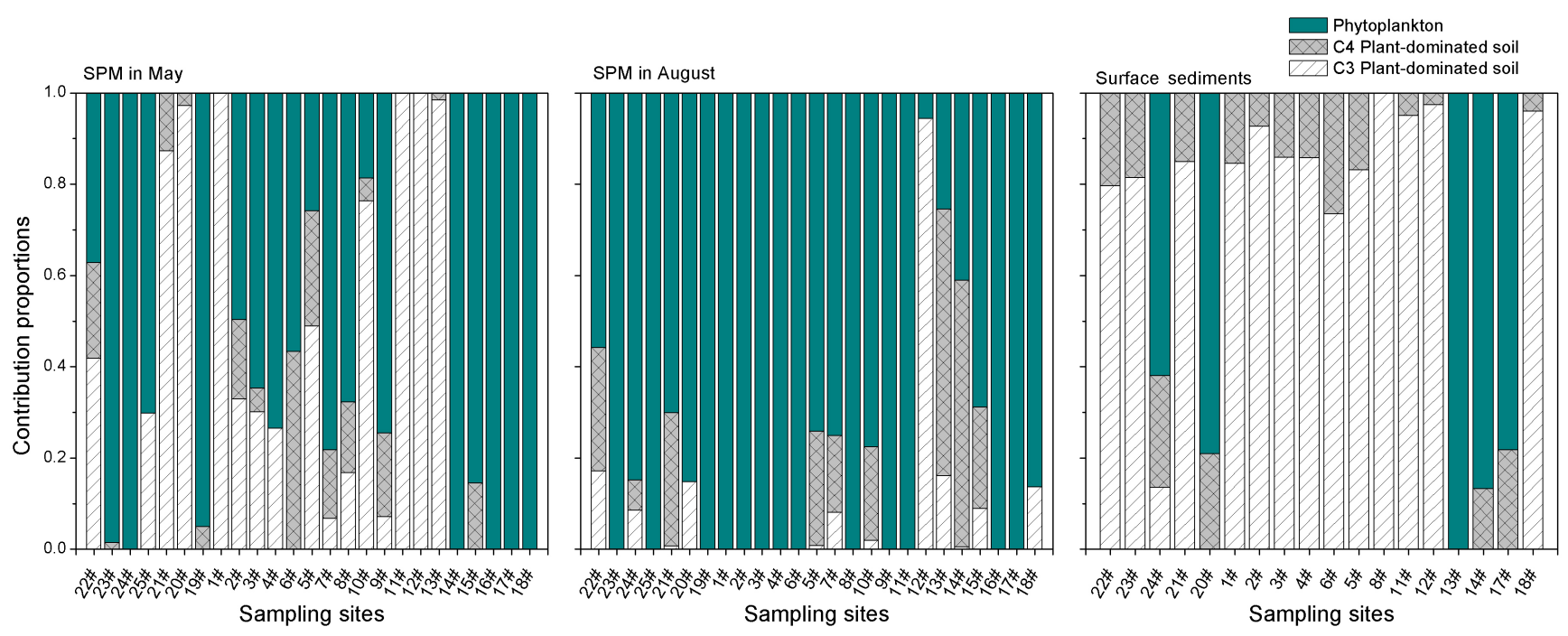

Figure 5. Contribution proportions of different sources to POC in suspended matters and surface sediments.

al., 2009). Phytoplankton was reported to have depleted $\delta^{13} \mathrm{C}$ values with a typical range of -42 to $-24 \%$ (Kendall et al., 2001 and references therein). The $\delta^{13} \mathrm{C}_{\mathrm{POC}}$ values of SPM were more negative in reservoir-affected sites than those less affected by reservoirs (Table 1). This could be due to the long water retention time of the reservoir, which was in favor of phytoplankton enhancement. The aquatic source increase in the reservoir was reported in other rivers (Chen and Jia, 2009; Zhang et al., 2009).

The contribution proportions were calculated by a mixing model based on the $\mathrm{C} / \mathrm{N}$ ratios and $\delta^{13} \mathrm{C}_{\mathrm{POC}}$ values. The $\mathrm{C} / \mathrm{N}$ of terrestrial source is assigned as 19.4 , which is the average $\mathrm{C} / \mathrm{N}$ value of soil and plants in the Wujiang watershed (Tao et al., 2009). Therefore, if $\mathrm{C} / \mathrm{N}>19.4$, the proportion of terrestrial source is $100 \%$. Other end-members of POC are shown in Fig. 4. The $\delta^{13} \mathrm{C}$ of phytoplankton end-member can be estimated based on the measured $\delta^{13} \mathrm{C}$ values of dissolved inorganic carbon $\left(\delta^{13} \mathrm{C}_{\mathrm{DIC}}\right)$ and an uptake fractionation of $21 \%$ (i.e., $\delta^{13} \mathrm{C}$ of phytoplankton $=\delta^{13} \mathrm{C}_{\text {DIC }}-21 \%$, Mook and Tan, 1991). Measured $\delta^{13} \mathrm{C}-\mathrm{DIC}$ (dissolved inorganic carbon) in the Wujiang River ranged from -11.55 to $-3.41 \%$, with an average value of $-8.67 \%$ o $(\mathrm{Li}$ and $\mathrm{Ji}$, 2016). Thus, the estimated $\delta^{13} \mathrm{C}$ values for phytoplankton ranged from -32.55 to $-24.41 \%$ with an average value of $-29.67 \%$. This results fell in the typical $\delta^{13} \mathrm{C}$ range $(-42$ to $-24 \%$ ) of freshwater plankton (Kendall et al., 2001 and references therein). This was also in accordance with the study by $\mathrm{Li}$ (2009) on the Maotiao River (a tributary of Wujiang River), where the average of $\delta^{13} \mathrm{C}_{\mathrm{POC}}$ of phytoplankton was $-29.6 \pm 5.5 \%$ o. The Wujiang River is the largest tributary of the upper Changjiang River in its south bank. Wu et al. (2007) reported the average $\delta^{13} \mathrm{C}$ value of soil endmember $(-26.1 \pm 0.3 \%$ o $)$ within the southern tributaries of the upper Changjiang River, which was taken as the upper limit of $\mathrm{C} 3$ plant-dominated soil end-member. The average $\delta^{13} \mathrm{C}$ of $\mathrm{C} 4$ plants in the catchment was $-13.4 \%$ o (Tao et al., 2009), which was taken as the upper limit of C4 plant sources. The corresponding equations of mixing model are as follows:

- If C / $\mathrm{N}<7$, the proportion of phytoplankton was $100 \%$.

- If $7<\mathrm{C} / \mathrm{N}<19.4$, the POC was derived from the mixing of phytoplankton, $\mathrm{C} 3$ plant-dominated soil and $\mathrm{C} 4$ plant-dominated soil. The corresponding mixing model is

$$
\begin{aligned}
& \delta^{13} \mathrm{C}_{\mathrm{POC}}=\delta^{13} \mathrm{C}_{\text {phyto }} \times f_{\text {phyto }}+\delta^{13} \mathrm{C}_{\mathrm{C} 3} \times f_{\mathrm{C} 3}+\delta^{13} \mathrm{C}_{\mathrm{C} 4} \times f_{\mathrm{C} 4}, \\
& \mathrm{C} / \mathrm{N}_{\mathrm{POC}}=\mathrm{C} / \mathrm{N}_{\text {phyto }} \times f_{\text {phyto }}+\mathrm{C} / \mathrm{N}_{\mathrm{C} 3} \times f_{\mathrm{C} 3}+\mathrm{C} / \mathrm{N}_{\mathrm{C} 4} \times f_{\mathrm{C} 4}, \\
& f_{\text {phyto }}+f_{\mathrm{C} 3}+f_{\mathrm{C} 4}=1 .
\end{aligned}
$$

The subscripts phyto, $\mathrm{C} 3$, and $\mathrm{C} 4$ represent the end-member of phytoplankton, $\mathrm{C} 3$ plant-dominated soil, and $\mathrm{C} 4$ plantdominated soil, respectively. The subscript POC denotes $\delta^{13} \mathrm{C}$ or $\mathrm{C} / \mathrm{N}$ values of samples measured in this study. The calculated results are presented in Fig. 5. POC of SPM was mainly derived from phytoplankton $(67 \%)$ and $\mathrm{C} 3$ plantdominated soil $(22 \%)$ with an increasing contribution of phytoplankton in August. The average phytoplankton contribution in sites directly affected by the reservoir was higher than sites less affected by reservoirs.

\subsubsection{Sources of POC in sediments}

$\mathrm{C} / \mathrm{N}$ ratios and the $\delta^{13} \mathrm{C}_{\mathrm{POC}}$ values of surface sediments reflected the compositions of organic matter in recent decades (Krull et al., 2009). C / N ratios of surface sediments ranged 


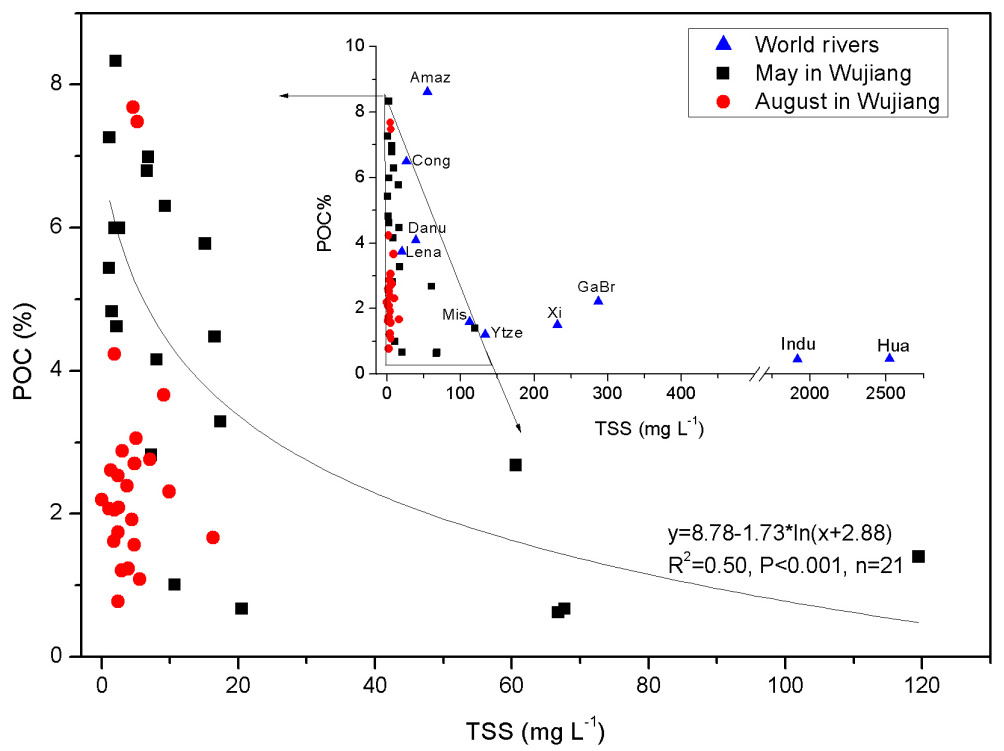

Figure 6. Correlations between TSS concentrations $\left(\mathrm{mg} \mathrm{L}^{-1}\right)$ and POC $(\%)$. The related data were summarized in Table 2. Amazon, Changjiang, Congo, Danube, Ganges-Brahmaputra, Huanghe, Indus, Lena, Mackenzie, Mississippi, St. Lawrence, Wujiang, Xijiang, Yenisey, and Zhujiang are abbreviated to Amaz, Chang, Cong, Danu, Gabr, Hua, Inds, Lena, Mack, Mis, StL, Wu, Xi, Yens, and Zhu, respectively.

from 7.7 to 41.1 with an average value of 18.0 , which verified the dominant terrestrial sources. Compared with SPM, the elevated $\mathrm{C} / \mathrm{N}$ ratios of surface sediments indicated more land-derived fraction contribution to the surface sediments. The POC and TN\% in surface sediments exhibited relatively strong correlation $\left(\mathrm{TN}=0.02 \times \mathrm{POC}+0.13, R^{2}=\right.$ $0.33, P=0.008)$. The intercept of the regression equation suggested that there was some inorganic nitrogen in the surface sediments. From June to August 2013, drought hit most parts of Guizhou Province. Soil organic matter and plant debris might be deposited and mineralized on the ground before they were transported into the rivers. Consequently, contents of organic components decreased and inorganic components increased, which might result in the weak correlation between POC and TN \%.

The relation of $\delta^{13} \mathrm{C}_{\mathrm{POC}}$ and $\mathrm{C} / \mathrm{N}$ in surface sediments (Fig. 4b) indicated that POC was mainly derived from terrestrial origin. In contrast with the SPM, the enriched $\delta^{13} \mathrm{C}_{\mathrm{POC}}$ values of surface sediments (averaging $-24.76 \%$ ) suggested that there was an increased source of $\mathrm{C} 4$ plants to sediments, and/or depleted carbon isotopes in surface sediment were not retained in the sediment (Guerra et al., 2013). Given that POC and TN contents were higher in most sediment samples than suspended sediments, the biodegradation of the phytoplankton was not the major cause of enrichment of $\delta^{13} \mathrm{C}_{\mathrm{POC}}$ values in surface sediments.

The contributions of different POC sources in surface sediments were calculated based on the similar equations in Sect. 4.1.1. Contribution of C3 plant-dominated soil and C4 plant-dominated soil averaged 64 and $13 \%$, respectively. The proportions of phytoplankton were lower than that in SPM. Spatial variation of source contribution was not significant in the surface sediment (Fig. 5), indicating that reservoir influence was relatively weak in surface sediment compared with those in SPM.

\subsection{Transformation of POC in the Wujiang River}

Knowledge of the POC transformation is useful to get a better understanding of the riverine carbon cycle. In-stream processes, such as assimilation and respiration of phytoplankton, affect the isotopic compositions and element contents of carbon and nitrogen. Hence, $\delta^{13} \mathrm{C}_{\mathrm{POC}}, \delta^{15} \mathrm{~N}_{\mathrm{TN}}$, and $\mathrm{C} / \mathrm{N}$ can be utilized to trace transformation processes of organic matter. The trend of increasing TSS concentrations with decreasing POC contents (\%, Fig. 6) indicated that POC contents (\%) of SPM were diluted with the inorganic constituents derived from soil erosion. This was similar to other rivers (Ludwig et al., 1996; Jiang and Ji, 2013; Zhang et al., 2009). The positive correlation between TSS concentrations and POC contents $\left(\mu \mathrm{mol} \mathrm{L}{ }^{-1}\right.$, Table S2) indicated that terrestrial organic matter was an important source of POC in SPM, which confirmed the erosion process. Although the erosion rate catchment decreased significantly in the Wujiang River (Wang, 2011), soil erosion had remarkable influence on the riverine carbon cycles.

$\delta^{15} \mathrm{~N}$ is a potential tracer to identify aquatic biogeochemical processes. High $\delta^{15} \mathrm{~N}$ may be caused by anthropogenic activities and transformation processes, such as denitrification and assimilation. Denitrification was excluded due to the weak correlation between $\delta^{15} \mathrm{~N}-\mathrm{NO}_{3}^{-}$and $\delta^{18} \mathrm{O}-\mathrm{NO}_{3}^{-}$ 

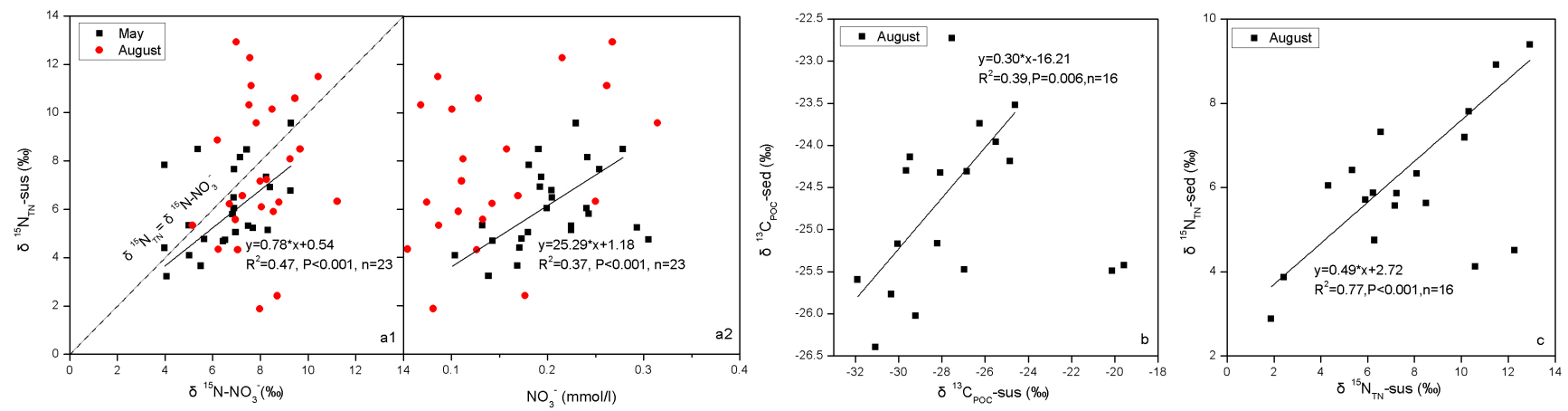

Figure 7. (a) Correlations of $\delta^{15} \mathrm{~N}_{\mathrm{TN}}$ values in suspended matters and $\delta^{15} \mathrm{~N}^{-\mathrm{NO}_{3}^{-}}$(a1) as well as $\mathrm{NO}_{3}^{-}$concentrations (a2) in corresponding river water in the Wujiang River; (b) Correlations of $\delta^{13} \mathrm{C}$ values between suspended matters (sus) and surface sediments (sed); (c) Correlations of $\delta^{15} \mathrm{~N}$ values between suspended matters and surface sediments.

(Li and Ji, 2016). Kendall et al. (2007) reported that animal waste and domestic effluents had typical values of $\delta^{15} \mathrm{~N}-$ $\mathrm{NO}_{3}^{-}>10 \%$. Some samples had high $\delta^{15} \mathrm{~N}_{\mathrm{TN}}$ values with elevated $\delta^{15} \mathrm{~N}-\mathrm{NO}_{3}^{-}$values $(>8 \%)$, indicating the inputs of manure and domestic sewage. Particulate organic carbon could be influenced by sewage water through the uptake of $\mathrm{NH}_{4}^{+}$and $\mathrm{NO}_{3}^{-}$by phytoplankton. Uptake of $\mathrm{NO}_{3}^{-}$with high $\delta^{15} \mathrm{~N}$ by phytoplankton might result in elevated $\delta^{15} \mathrm{~N}_{\mathrm{TN}}$ values (Kendall et al., 2001; Jiang and Ji, 2013). This process was confirmed by the significant positive correlation of $\delta^{15} \mathrm{~N}_{\mathrm{TN}}-\mathrm{SPM}$ vs. $\delta^{15} \mathrm{~N}-\mathrm{NO}_{3}^{-}$and $\delta^{15} \mathrm{~N}_{\mathrm{TN}}-\mathrm{SPM}$ vs. $\mathrm{NO}_{3}^{-}$ in May (Fig. 7a). However, some samples with $\delta^{15} \mathrm{~N}_{\mathrm{TN}}-$ SPM $>10 \%$ ( $\delta^{15} \mathrm{~N}-\mathrm{NO}_{3}^{-}<8 \%$ ) (Fig. 7a) deviated from other data in August, indicating other influencing factors. One mechanism might be related to uptake of other forms of dissolved inorganic nitrogen. The drought event during June to August created a longer time for the mineralization of soil organic matter, favorable to the production of ammonia with heavy $\delta^{15} \mathrm{~N}$ values. The elevated $\delta^{15} \mathrm{~N}_{\mathrm{TN}}-\mathrm{SPM}$ might be caused by the uptake of nitrification-derived $\mathrm{NH}_{4}^{+}$, as nitrifiers preferentially consumed ${ }^{14} \mathrm{~N}$, leading to an increase in $\delta^{15} \mathrm{~N}-\mathrm{NH}_{4}^{+}$of the remaining ammonia. Consumption of such enriched ${ }^{15} \mathrm{~N}-\mathrm{NH}_{4}^{+}$by phytoplankton resulted in the scattered trend of $\delta^{15} \mathrm{~N}_{\mathrm{TN}}-\mathrm{SPM}$ in August. A similar result was observed in the study by Sarma et al. (2012).

Positive correlations of $\delta^{13} \mathrm{C}_{\mathrm{POC}}$ (Fig. 7b) and $\delta^{15} \mathrm{~N}_{\mathrm{TN}}$ (Fig. 7c) between suspended and surface sediments indicated that an intense exchange might exist in these two carbon pools (Jiang and Ji, 2013; Sarma et al., 2012). The resuspension/deposition of suspended matter with mixing of different organic matter sources might result in the significant correlation of $\delta^{13} \mathrm{C}_{\mathrm{POC}}$ (Fig. 7b) and $\delta^{15} \mathrm{~N}_{\mathrm{TN}}$ (Fig. 7c). Compared with suspended matter, the heavier $\delta^{13} \mathrm{C}_{\mathrm{POC}}$ and lighter $\delta^{15} \mathrm{~N}_{\mathrm{TN}}$ in sediments indicated an enriched source of refractory allochthonous organic matter. The good correlations between river water and SPM as well as surface sediment indicated that these carbon pools were tightly connected.

\subsection{Flux of POC in Wujiang River and comparison with world rivers}

Flux of POC $\left(F_{\mathrm{POC}}\right)$ was estimated based on a simple method from Tao et al. (2009):

$$
\begin{aligned}
& F_{\mathrm{POC}}=[\mathrm{POC}]_{\mathrm{H}} \times \text { Discharge } \times 66 \%+[\mathrm{POC}]_{\mathrm{L}} \\
& \quad \times \text { Discharge } \times 34 \%,
\end{aligned}
$$

where $[\mathrm{POC}]_{\mathrm{H}}$ and $[\mathrm{POC}]_{\mathrm{L}}$ is the average $\mathrm{POC}$ concentration of SPM in high-water season and low-water season, respectively. The POC concentration of river mouth (sample 18 in Fig. 1) was used to calculate the POC flux. Water discharge of the Wujiang River in 2013 (website: www.cjw.gov.cn) was taken from the Wulong hydrologic station, which was close to the river mouth. Discharge in high-flow and low-flow season accounted for 66 and $34 \%$ of the annual discharge in 2013, respectively (Changjiang Sediment Bulletin, 2013). Since the water discharge in May was the almost its highest compared with other months (Fig. 2), the POC concentration in May collected at the river mouth (site 18 in Fig. 1) was used to calculate the POC flux in high-water season. Similarly, POC concentration in August was used to calculate the POC flux in low-water season since water discharge in August was close to that in low-water season (Fig. 2). The estimated POC flux was $1.17 \times 10^{10} \mathrm{~g}$ in 2013 , lower than that in the Wujiang River determined by Tao et al. (2009) in 2002. The decrease in POC flux might be due to measures of soil and water conservation, dam construction (Wu et al., 2007) as well as decreased discharge due to extreme drought in 2013 in Guizhou Province.

In Table 2 water discharge, TSS concentration, POC \%, POC flux, and yield were compared with 15 world rivers. The total drainage area of the 15 rivers amounted to $30.3 \times 10^{6} \mathrm{~km}^{2}$ (Table 2), accounting for $55 \%$ of the 60 world rivers' area from the study of Gaillardet et al. (1999). As shown in Table 2, the very low POC yield in the Wujiang River was the forth lowest observed in the rivers documented before Yenisey, Ob, and St. Lawrence. In com- 

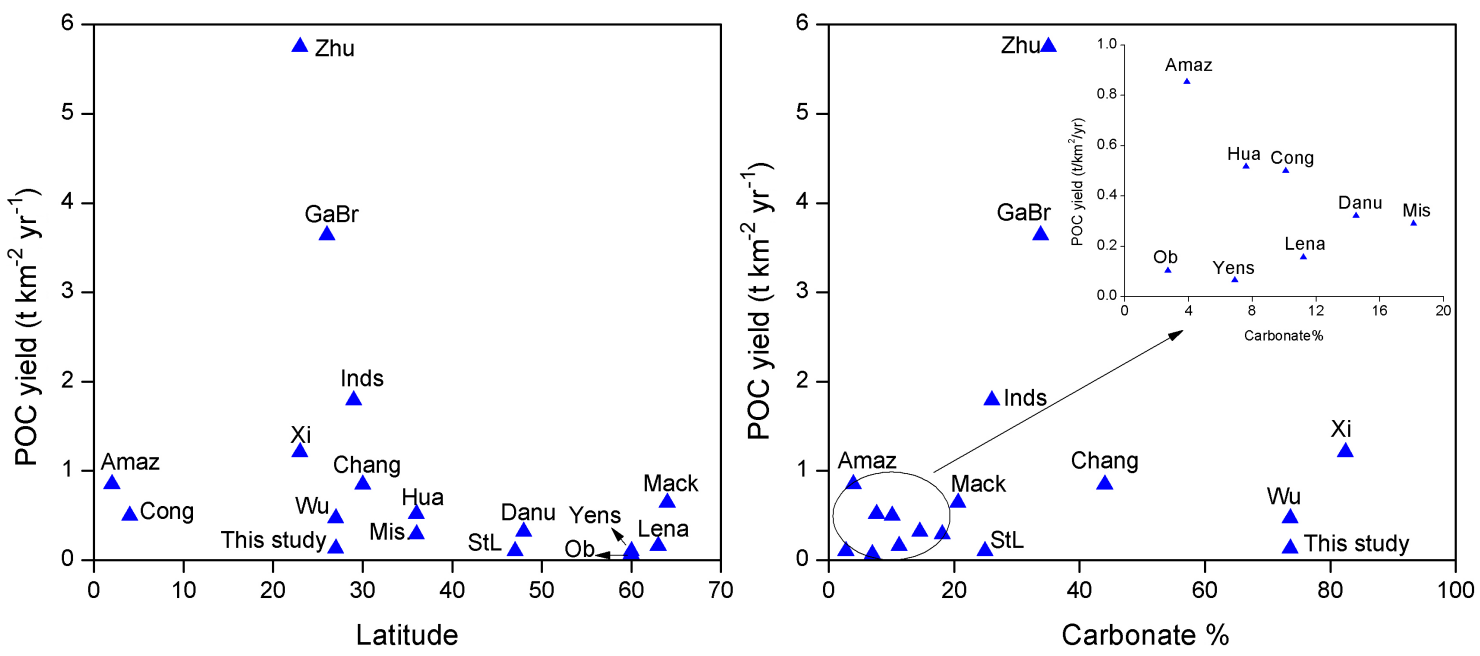

Figure 8. (a) Relationship between POC yield and latitude; (b) Relationship between POC yield and percentage of carbonate area (carbonate $\%$ ). Latitude and percentage of carbonate area were taken from Cai et al. (2008) and Amiotte Suchet et al. (2003), respectively.

Table 2. Particulate organic carbon fluxes (FPOC) and yields (YPOC) in some world rivers and the Wujiang River.

\begin{tabular}{|c|c|c|c|c|c|c|c|c|c|}
\hline River & $\begin{array}{r}\text { Area } \\
10^{3} \mathrm{~km}^{2}\end{array}$ & Latitude $^{1}$ & $\begin{array}{l}\text { Discharge } \\
\mathrm{km}^{3} \mathrm{yr}^{-1}\end{array}$ & $\begin{array}{r}\text { Carbonate }^{2} \\
\%\end{array}$ & $\begin{array}{r}\mathrm{TSS} \\
\mathrm{mgL} \mathrm{L}^{-1}\end{array}$ & $\begin{array}{r}\text { POC } \\
\%\end{array}$ & $\begin{array}{r}\text { FPOC } \\
\mathrm{Mt} \mathrm{yr}^{-1}\end{array}$ & $\begin{array}{r}\text { YPOC } \\
\mathrm{t} \mathrm{km}^{-2} \mathrm{yr}^{-1}\end{array}$ & Source \\
\hline Amazon & 5854 & 2 & 6642 & 3.9 & 54.7 & 8.62 & 5.00 & 0.85 & Moreira-Turcq et al. (2003) \\
\hline Changjiang & 1794 & 30 & 779 & 44 & 134 & 1.21 & 1.52 & 0.85 & Wang et al. (2012) \\
\hline Congo/Zaire & 3699 & 4 & 1325 & 10.1 & 26 & 6.5 & 2.00 & 0.50 & Coynel et al. (2005) \\
\hline Danube & 788 & 48 & 207 & 14.5 & 39 & 4.10 & 0.25 & 0.32 & Reschke et al. (2002) \\
\hline Ganges-Brahmaputra & 1648 & 26 & 1313 & 33.8 & 287 & 2.23 & 6.00 & 3.64 & Aucour et al. (2006) \\
\hline Huanghe & 752 & 36 & 13 & 7.6 & 2522 & 0.48 & 0.39 & 0.52 & Wang et al. (2012) \\
\hline Indus & 1143 & 29 & 104 & 26 & 1917 & 0.46 & 2.05 & 1.79 & Ludwig et al. (1996) \\
\hline Lena & 2418 & 63 & 525 & 11.2 & 20 & 3.75 & 0.38 & 0.16 & Semiletov et al. (2011) \\
\hline Mackenzie & 1713 & 64 & 290 & 20.6 & - & - & 1.10 & 0.64 & Carrie et al. (2009) \\
\hline Mississippi & 3203 & 36 & 610 & 18.1 & 112 & 1.6 & 0.93 & 0.29 & Bianchi et al. (2007) \\
\hline $\mathrm{Ob}$ & 2990 & 60 & 412 & 2.7 & - & - & 0.31 & 0.10 & Köhler et al. (2003) \\
\hline St. Lawrence & 1267 & 47 & 363 & 24.9 & - & - & 0.13 & 0.10 & Hélie (2004) \\
\hline Wujiang River & 67 & 27 & 38 & $73.6^{3}$ & 25.99 & 9.21 & 0.03 & 0.47 & Tao et al. (2009) \\
\hline Wujiang River & 88 & 27 & 33 & $73.6^{3}$ & 38 & 1.47 & 0.01 & 0.13 & This study \\
\hline Xijiang & 353 & 23 & 182 & 82.4 & 232 & 1.5 & 0.43 & 1.21 & Sun et al. (2007) \\
\hline Yenisey & 2580 & 60 & 599 & 6.9 & - & - & 0.17 & 0.07 & Köhler et al. (2003) \\
\hline Zhujiang & 427 & 23 & 343 & 35 & - & - & 2.50 & 5.75 & Zhang et al. (2013) \\
\hline $\operatorname{Mean}(\mathrm{M})$ or Sum(S) & $30276(\mathrm{~S})$ & $38(\mathrm{M})$ & $13525(\mathrm{~S})$ & $18.5(\mathrm{M})$ & $568(\mathrm{M})$ & $3.22(\mathrm{M})$ & $22.73(\mathrm{~S})$ & $1.11(\mathrm{M})$ & \\
\hline
\end{tabular}

${ }^{1}$ Cai et al. (2008). ${ }^{2}$ Amiotte Suchet et al. (2003). ${ }^{3}$ Carbonate \% in Wujiang was in reference to the carbonate distribution inside Guizhou Porvince (Wan, 1995). ${ }^{4}$ Xijiang and Wujiang, as tributaries of Zhujiang and Changjiang, respectively, were not included in the statistical data.

parison, the first two rivers in terms of POC yield were Zhujiang and Ganges-Brahmaputra with POC yield higher than $3 \mathrm{t} \mathrm{km}^{-2} \mathrm{yr}^{-1}$. Both Zhujiang and Ganges-Brahmaputra were located in the mid-latitude, subject to tropical and subtropical climate. The latitudinal distribution patterns of POC yield were examined for the 15 world rivers and Wujiang River (Fig. 8a). As shown in the Fig. 8a, POC yields were higher in the mid-latitude rivers and tended toward the subtropical rivers. This was similar to the distribution feature of $\mathrm{HCO}_{3}^{-}$yield for the world rivers in the study of Cai et al. (2008). According to Amiotte Suchet et al. (2003), carbonate rocks were mainly distributed between 20 and $50^{\circ} \mathrm{N}$. The carbonated area in the documented 15 world rivers ac- counted for $8 \%$ of the 60 world rivers' area, while POC flux accounted for $13 \%$ of the global POC flux of $0.17 \mathrm{Gt}\left(10^{15} \mathrm{~g}\right)$ estimated by Ludwig et al. (1996). It appeared that more carbonate would result in elevated POC export. Unfortunately, no clear correlation was found between carbonate percentage and POC yields (Fig. 8b), which indicated that percentage of carbonate area was not a significant factor of riverine POC transport. This was not similar to Mackenzie River, where organic-rich sedimentary rocks contributed a significant particulate organic matter (Carrie et al., 2009). However, the influence of carbonate might be underestimated as discussed by Cai et al. (2008) since carbonate rocks were defined as those 
that contained up to $50 \%$ of carbonate minerals (Amiotte Suchet et al., 2003).

Compared with the previous study in Wujiang River, the POC yield decreased from $0.47 \mathrm{t} \mathrm{km}^{-2} \mathrm{yr}^{-1}$ (Tao et al., 2009) to $0.13 \mathrm{t} \mathrm{km}^{-2} \mathrm{yr}^{-1}$ (Table 2). It was noted that five dams were constructed in the lower reaches of the Wujiang River after the study of Tao et al. (2009). Moreover, POC yield in the Wujiang River was much lower than that in Xijiang and Zhujiang with a high carbonate percentage. This could be related to the smaller watershed area and extensive water reservoirs in the Wujiang River (Zhang et al., 2006). The impacts of reservoirs will be discussed below.

\subsection{Impacts of reservoirs and climate on riverine POC}

There are eleven artificial dams along the mainstream of $\mathrm{Wu}$ jiang River (Fig. 1). The cascade of reservoirs created by dams may exert significant impacts on source and transport of riverine POC. In addition, extreme drought must be noted when considering the meteorological characteristics of the Wujiang River in 2013.

$\delta^{13} \mathrm{C}$ and $\delta^{15} \mathrm{~N}$ proved to be potentially useful indicators for qualitative estimation of reservoirs and climatic impact on POC in dam-affected rivers (Chen and Jia, 2009; Zhang et al., 2009). In order to analyze the reservoir impact on riverine POC, $\delta^{13} \mathrm{C}$ and $\delta^{15} \mathrm{~N}$ values were compared in sites directly affected by dams with those less affected in the Wujiang River (Table 1). As shown in Table $1, \delta^{13} \mathrm{C}$ were more depleted in sites affected by dam than those less affected by dam. This was similar to the study by Chen and Jia (2009) in a dam-controlled river. Compared with sites far from the dam, the more depleted values of $\delta^{13} \mathrm{C}$ in sites close to dam were attributed to increasing phytoplankton contribution. This was confirmed by the higher phytoplankton contribution to POC of SPM in sites directly affected by dam with an average of $47 \%$ relative to those less affected with an average of $27 \%$. Two mechanisms could explain this elevated phytoplankton contribution: (1) extended water retention time in reservoirs with low flow; (2) increasing light availability due to the low TSS concentrations (Table 1) in reservoirs. In contrast with $\delta^{13} \mathrm{C}$ values, $\delta^{15} \mathrm{~N}$ values were heavier in sites close to reservoirs than those far from reservoirs. Delong and Thorp (2006) reported that $\delta^{15} \mathrm{~N}$ values in aquatic algal were more enriched than detrital fraction. Thus, the heavier $\delta^{15} \mathrm{~N}$ values in sites directly affected by dams might result from the aquatic algal and plankton. This hypothesis was verified by the concurrent lighter $\delta^{13} \mathrm{C}$ values and lower $\mathrm{C} / \mathrm{N}$ ratios in the sites directly influenced by reservoirs (Table 1). Moreover, denitrification could be another cause for the heavier $\delta^{15} \mathrm{~N}$ values in the reservoirs since hypoxic environments might occur in the deep water. Further study of $\delta^{15} \mathrm{~N}$ variations in different water depths could help to trace the denitrification process. Seasonally, the average $\delta^{13} \mathrm{C}$ values in August at sites directly affected by reservoirs $(-28.65 \%$ ) were much higher than other sites $(-26.68 \%$ o).
This large difference could be related to the higher temperature and extreme drought during June to August, which was favorable to in situ phytoplankton production. According to Chen and Jia (2009), accumulated terrestrial organic matters in winter were flushed during the first heavy rain, which resulted in increasing terrestrial input in the onset of the wet season. This could also be the reason for the Wujiang River in May, when the water discharge increased abruptly.

It is difficult to quantitatively evaluate the impact of dams and extreme drought. The method described in the study of Yu et al. (2011) made it possible to distinguish the impact of dams and climate. This method was based on the significant correlation between POC flux and suspended sediment load. Thus, the variations of suspended sediment load could reflect the POC flux variations under the condition of dam and extreme drought. The comparison of suspended sediment loads was made between normal years and the drought year 2013 in the Wulong hydrologic station, at the mouth of Wujiang River (Table S3). As shown in Table S3, the suspended sediment loads in 2013 at Wulong station reduced by $80 \%$ compared with normal years, which could be due to the combined impacts of cascade of dams and extreme drought. Because suspended sediment at Wulong station directly flowed into Three Gorges Dam (TGD), the impact of climate on TGD sediment revealed the similar impacts on Wulong station. The impacts of extreme drought can be estimated based on the comparison of sediment inputs to TGD between normal and drought years. The reduction $41 \%$ of sediment inputs to TGD was obtained in 2013 compared with normal years, which was attributed to the climate impact. Thus, the impact of cascade of dams was $39 \%$. The normalized impacts of cascade of dams and extreme drought were 49 and $51 \%$, respectively. This result was similar to the impacts of extreme drought in 2006 on TGD determined by Yu et al. (2011). This result indicated that extreme drought and dams were important factors of suspended sediment load. Considering the significant correlation between TSS concentrations and POC concentrations (Table S2), reservoirs and extreme drought had a similar impact on the POC transport. However, this estimation based on the Wujiang River mouth was limited relative to the whole basin.

\section{Conclusions}

The carbon to nitrogen ratios and its isotopic compositions of POC were determined in suspended and surface sediments in the Wujiang River. The results indicated that POC in SPM was mainly derived from phytoplankton and C3-dominated soil with increased phytoplankton input in sites affected by reservoirs. In comparison, POC in surface sediments was mainly derived from C3- and C4-dominated soil. The relationships of carbon and nitrogen isotopes between suspended and surface sediments indicated that these two carbon pools are closely coupled. An in-stream process, such as micro- 
biological decomposition in water column and surface sediments, might result in the difference in terms of POC sources between suspended and surface sediments. POC transported $1.17 \times 10^{10} \mathrm{~g}$ to the Three Gorges Reservoir in 2013. POC yield in Wujiang River $\left(0.13 \mathrm{t} \mathrm{km}^{-2} \mathrm{yr}^{-1}\right)$ was much lower than large rivers with high carbonate percentage. The carbonate distribution patterns of POC yield indicated that percentage of carbonate area was not a significant factor of riverine POC transport. The cascade of reservoirs and extreme drought had a significant influence on the POC flux in $\mathrm{Wu}-$ jiang River.

\section{Data availability}

All data used in this publication will be provided upon request by the corresponding author.

\section{The Supplement related to this article is available online at doi:10.5194/bg-13-3687-2016-supplement.}

Author contributions. These authors were responsible for the following: research plan - Hongbing Ji; experimental design - Cai Li, Hongbing Ji; financial support - Hongbing Ji; methodology (XRD, isotopes, statistical analysis) - Cai $\mathrm{Li}$, Hongbing Ji; experimental implementation and data analysis - Cai Li, Huaijian Ding, Yang, Gao, Hongbing $\mathrm{Ji}$; manuscript drafting and reviewing - Cai Li, Hongbing $\mathrm{Ji}$; and hydrological and carbonate chemistry data support - Huaijian Ding, Yang Gao.

Acknowledgements. We appreciate Meryem Briki for her help in the field. This work was financially supported by the National Natural Science Foundation of China (no. 41473122), the National Key Basic Research and Development Program (no. 2013CB956702) and the Hundred Talents Programs of Chinese Academy of Sciences.

Edited by: M. Sarin

\section{References}

Amiotte Suchet, P., Probst, J. L., and Ludwig, W.: Worldwide distribution of continental rock lithology: implications for the atmospheric/soil $\mathrm{CO}_{2}$ uptake by continental weathering and alkalinity river transport to the oceans, Global Biogeochem. Cy., 17, 7-1, 2003.

Aucour, A. M., France-Lanord, C., Pedoja, K., Pierson-Wickmann, A. C., and Sheppard, S. M. F.: Fluxes and sources of particulate organic carbon in the Ganga-Brahmaputra river system, Global Biogeochem. Cy., 20, GB2006, doi:10.1029/2004GB002324, 2006.
Bao, H. Y., Wu, Y., Zhang, J., Deng, B., and He, Q.: Composition and flux of suspended organic matter in the middle and lower reaches of the Changjiang (Yangtze River)-impact of the Three Gorges Dam and the role of tributaries and channel erosion, Hydrol. Process., 28, 2877-2877, 2014.

Bianchi, T. S., Wysocki, L. A., Stewart, M., Filley, T. R., and Mckee, B. A.: Temporal variability in terrestrially-derived sources of particulate organic carbon in the lower Mississippi River and its upper tributaries, Geochim. Cosmochim. Ac., 71, 4425-4437, 2007.

Cai, W. J., Guo, X., Chen, C. T. A., Dai, M., Zhang, L., Zhai, W., Lohrena, S. E., Yin, K., Harrison, P. J., and Wang, Y.: A comparative overview of weathering intensity and $\mathrm{HCO}_{3}^{-}$flux in the world's major rivers with emphasis on the Changjiang, Huanghe, Zhujiang (Pearl) and Mississippi Rivers, Cont. Shelf Res., 28, 1538-1549, 2008.

Carrie, J., Sanei, H., Goodarzi, F., Stern, G. and Wang, F.: Characterization of organic matter in surface sediments of the Mackenzie River basin, Canada, Int. J. Coal Geol., 77, 416-423, 2009.

Changjiang Sediment Bulletin: http://www.cjw.gov.cn/ (last access: 13 November 2015), 2013.

Chen, F. and Jia, G.: Spatial and seasonal variations in $\delta^{13} \mathrm{C}$ and $\delta^{15} \mathrm{~N}$ of particulate organic matter in a dam-controlled subtropical river, River Res. Appl., 25, 1169-1176, 2009.

Coynel, A., Seyler, P., Etcheber, H., Meybeck, M., and Orange, D.: Spatial and seasonal dynamics of total suspended sediment and organic carbon species in the Congo River, Global Biogeochem. Cy., 19, GB4019, doi:10.1029/2004GB002335, 2005.

Delong, M. D. and Thorp, J. H.: Significance of instream autotrophs in trophic dynamics of the Upper Mississippi River, Oecologia, 147, 76-85, 2006.

Ding, T., Gao, J., Tian, S., Shi, G., Feng, C., Wang, C., Luo, X., and Han, D.: Chemical and isotopic characteristics of the water and suspended particulate materials in the Yangtze river and their geological and environmental implications, Acta Geol. SinEngl., 88, 276-360, 2014.

Gaillardet, J., Dupre, B., Louvat, P., and Allegre, C. J.: Global silicate weathering and $\mathrm{CO}_{2}$ consumption rates deduced from the chemistry of large rivers, Chem. Geol., 159, 3-30, doi:10.1016/S0009-2541(99)00031-5, 1999.

Guerra, R., Pistocchi, R., and Vanucci, S.: Dynamics and sources of organic carbon in suspended particulate matter and sediments in Pialassa Baiona lagoon (NW Adriatic Sea, Italy), Estuar. Coast. Shelf S., 135, 24-32, 2013.

Hedges, J. I., Keil, R. G., and Benner, R.: What happens to terrestrial organic matter in the ocean?, Org. Geochem., 27, 195-212, 1997.

Hélie, J. F.: Geochemistry and fluxes of organic and inorganic carbon in aquatic systems of eastern Canada: examples of the St. Lawrence River and Robert-Bourassa Reservoir: isotopic approach, Ph.D. thesis, University of Quebec in Montreal, Canada, 204 pp., 2004.

Hellings, L., Dehairs, F., Tackx, M., Keppens, E., and Baeyens, W. Origin and fate of organic carbon in the freshwater part of the Scheldt Estuary as traced by stable carbon isotope composition, Biogeochemistry, 47, 167-186, 1999.

Hu, J., Peng, P. A., Jia, G., Mai, B., and Zhang, G.: Distribution and sources of organic carbon, nitrogen and their isotopes in sed- 
iments of the subtropical Pearl River estuary and adjacent shelf, Southern China, Mar. Chem., 98, 274-285, 2006.

Jiang, Y. and Ji, H.: Isotopic indicators of source and fate of particulate organic carbon in a karstic watershed on the YunnanGuizhou Plateau. Appl. Geochem., 36, 153-167, 2013.

Kao, S. J. and Liu, K. K.: Particulate organic carbon export from a subtropical mountainous river (Lanyang Hsi) in Taiwan, Limnol. Oceanogr., 41, 1749-1757, 1996.

Kendall, C., Silva, S. R., and Kelly, V. J.: Carbon and nitrogen isotopic compositions of particulate organic matter in four large river systems across the United States, Hydrol. Process., 15, 1301-1346, 2001.

Kendall, C., Elliott E. M., and Wankel, S. D.: Tracing anthropogenic inputs of nitrogen to ecosystems, in: Stable isotopes in ecology and environmental science, second edn., Blackwell, Oxford, 375-449, 2007.

Köhler, H., Meon, B., Gordeev, V. V., Spitzy, A., Amon, R. M. W., and Shirshov, P. P.: Dissolved organic matter (DOM) in the estuaries of $\mathrm{Ob}$ and Yenisei and the adjacent Kara Sea, Russia, $\mathrm{P}$. Mar. Sci., 6, 281-308, 2003.

Krull, E., Haynes, D., Lamontagne, S., Gell, P., Mckirdy, D., Hancock, G., Mcgowan, J., and Smernik, R.: Changes in the chemistry of sedimentary organic matter within the Coorong over space and time, Biogeochemistry, 92, 9-25, 2009.

Li, C. and Ji, H. B.: Chemical weathering and the role of sulfuric and nitric acids in carbonate weathering: Isotopes $\left({ }^{13} \mathrm{C},{ }^{15} \mathrm{~N}\right.$, ${ }^{34} \mathrm{~S}$, and ${ }^{18} \mathrm{O}$ ) and chemical constraints, J. Geophy. Res. Biogeo., 121, 1288-1305, doi:10.1002/2015JG003121, 2016.

Li, G. R.: Cascade Damming of the River and its Phytoplankton Evolution Carbon Isotope Compositions - A Case Study of Maotiao River drainage area in Guizhou Province, PhD Dissertation, Guizhou Normal Univ., China, 2009 (in Chinese with English abstract).

Liu, C. Q.: The Process of Biogeochemistry and the Cycle of Surface Mass Riverine Erosion and Elemental cycle in Southwest China, Science Press, Beijing, 2007 (in Chinese).

Ludwig, W., Probst, J. L., and Kempe, S.: Predicting the oceanic input of organic carbon by continental erosion, Global Biogeochem Cy., 10, 23-41, 1996.

Moreira-Turcq, P., Seyler, P., Guyot, J. L., and Etcheber, H.: Exportation of organic carbon from the Amazon River and its main tributaries, Hydrol. Process., 17, 1329-1344, 2003.

Meybeck, M. and Ragu, A.: River discharges to the oceans: An assessment of suspended solids, major ions, and nutrients, environment information and assessment report, 250 pp., U.N. Environ. Programme, Nairobi, 1996.

Meyers, P. A.: Organic geochemical proxies of paleoceanographic, pleolimnologic, and paleoclimatic processes, Org. Geochem., 27, 213-250, 1997.

Mook, W. G. and Tan, F. C.: Stable carbon isotopes in rivers and estuaries, in: Biogeochemistry of Major World Rivers, edited by: Degens, E. T., Kempe, S., and Richy, J. E., Wiley, New York, 245-264, 1991.

Ogrinc, N., Markovics, R., Kanduc, T., Walter, L. M., and Hamilton, S.: Sources and transport of carbon and nitrogen in the River Sava watershed, a major tributary of the River Danube, Appl. Geochem., 23, 3685-3698, 2008.
Reschke, S., Ittekkot, V., and Panin, N.: The nature of organic matter in the Danube river particles and north-western black sea sediments, Estuar. Coast. Shelf S., 54, 563-574, 2002.

Sarma, V. V. S. S., Arya, J., Subbaiah, C. V., Naidu, S. A., Gawade, L., Kumar, P. P., and Reddy, N. P. C.: Stable isotopes of carbon and nitrogen in suspended matter and sediments from the Godavari estuary, J. Oceanogr., 68, 307-319, 2012.

Schlesinger, W. H. and Melack, J. M.: Transport of organic carbon in the world's rivers, Tellus, 33,172-187, 1981.

Semiletov, I. P., Pipko, I. I., Shakhova, N. E., Dudarev, O. V., Pugach, S. P., Charkin, A. N., McRoy, C. P., Kosmach, D., and Gustafsson, Ö.: Carbon transport by the Lena River from its headwaters to the Arctic Ocean, with emphasis on fluvial input of terrestrial particulate organic carbon vs. carbon transport by coastal erosion, Biogeosciences, 8, 2407-2426, doi:10.5194/bg8-2407-2011, 2011.

Smith, B. N. and Epstein, S.: Categories of ${ }^{13} \mathrm{C} /{ }^{12} \mathrm{C}$ ratios for higher plants, Plant Physiol., 47, 380-384, 1971.

Sun, H. G., Han, J. T., Zhang, S. R., and Lu, X. X.: The impacts of '05.6' extreme flood event on riverine carbon fluxes in Xijiang River, Chinese Sci. Bull., 52, 805-812, 2007.

Tao, F. X., Liu, C. Q., and Li, S. L.: Source and flux of POC in two subtropical karstic tributaries with contrasting land use practice in the Yangtze River Basin, Appl. Geochem., 24, 2102-2112, 2009.

Tremblay, L. and Benner, R.: Microbial contributions to Nimmobilization and organic matter preservation in decaying plant detritus, Geochim. Cosmochim. Ac., 70, 133-146, 2006.

Wan, G. J.: Carbonates and Environment (Vol. I), Beijing: Seismological Press, 1995.

Wang, X., Ma, H., Li, R., Song, Z., and Wu, J.: Seasonal fluxes and source variation of organic carbon transported by two major Chinese Rivers: The Yellow River and Changjiang (Yangtze) River, Global Biogeochem. Cy., 26, GB2025, doi:10.1029/2011GB004130, 2012.

Wang, Y.: Simulation study on soil erosion in karst area-a case study of Wujiang River in Guizhou Province, Ph.D. Dissertation, Peking University, 2011 (in Chinese).

Wu, Y., Zhang, J., Liu, S. M., Zhang, Z. F., Yao, Q. Z., Hong, G. H., and Cooper, L.: Sources and distribution of carbon within the Yangtze River system, Estuar. Coast. Shelf S., 71, 13-25, 2007.

Yu, H., Wu, Y., Zhang, J., Deng, B. and Zhu, Z.: Impact of extreme drought and the Three Gorges Dam on transport of particulate terrestrial organic carbon in the Changjiang (Yangtze) River, J. Geophys. Res., 116, F04029, doi:10.1029/2011JF002012, 2011.

Zhang, L. C., Yu, Z. S., and Zhang, S.: Chemical elements in Changjiang River system monograph series (2): study on chemical elements in water environment, China Environmental Science Press, Beijing, 1995 (in Chinese).

Zhang, L. K., Qin, X. Q., Yang, H., Huang, Q. B. and Liu, P. Y.: Transported fluxes of the riverine carbon and seasonal variation in Pearl River Basin, Environ. Sci., 34, 3025-3034, 2013 (in Chinese).

Zhang, Q., Xu, C. Y., Becker, S., and Jiang, T.: Sediment and runoff changes in the Yangtze River basin during past 50 years, J. Hydrol., 331, 511-523, doi:10.1016/j.jhydrol.2006.05.036, 2006. 
Zhang, S., Lu, X. X., Sun, H., Han, J., and Higgitt, D. L.: Geochemical characteristics and fluxes of organic carbon in a humandisturbed mountainous river (the Luodingjiang River) of the Zhujiang (Pearl River), China, Sci. Total Environ., 407, 815-825, 2009. 